\title{
A Quantitative Assessment of the Prion Risk Associated with Wastewater from Carcase-Handling Facilities
}

\author{
Amie Adkin, ${ }^{1, *}$ Neil Donaldson, ${ }^{1}$ and Louise Kelly ${ }^{1,2}$
}

\begin{abstract}
Wastewater from facilities processing livestock that may harbor transmissible spongiform encephalopathies (TSEs) infectivity is permitted under license for application to land where susceptible livestock may have access. Several previous risk assessments have investigated the risk of bovine spongiform encephalopathy (BSE) associated with wastewater effluents; however, the risk of exposure to classical scrapie and atypical scrapie has not been assessed. With the prevalence of certain TSEs (BSE in cattle and classical scrapie in sheep) steadily in decline, and with considerable changes in the structure of carcase-processing industries in Great Britain, a reappraisal of the TSE risk posed by wastewater is required. Our results indicate that the predicted number of new TSE infections arising from the spreading of wastewater on pasture over one year would be low, with a mean of one infection every 1,000 years for BSE in cattle $(769,555,556)$, and one infection every 30 years $(16,2,500)$, and 33 years $(16$, $3,333)$ for classical and atypical scrapie, respectively. It is assumed that the values and assumptions used in this risk assessment remain constant. For BSE in cattle the main contributors are abattoir and rendering effluent, contributing $35 \%$ and $22 \%$ of the total number of new BSE infections. For TSEs in sheep, effluent from small incinerators and rendering plants are the major contributors (on average $32 \%$ and $31 \%$ of the total number of new classical scrapie and atypical scrapie infections). This is a reflection of the volume of carcase material and Category 1 material flow through such facilities.
\end{abstract}

KEY WORDS: Abattoir; bovine spongiform encephalopathy; QRA; scrapie; TSE

\section{INTRODUCTION}

In Great Britain, the occurrence of some prion diseases in cattle and sheep (bovine spongiform encephalopathy [BSE] and classical scrapie in sheep)

${ }^{1}$ Epidemiology, Surveillance and Risk Group, Animal Health and Veterinary Laboratories Agency, Woodham Lane, Weybridge, KT15 3NB, UK.

${ }^{2}$ Department of Mathematics and Statistics, University of Strathclyde, Richmond Street, Glasgow, G1 1XH, UK.

*Address correspondence to Amie Adkin, Epidemiology, Surveillance and Risk Group, Animal Health and Veterinary Laboratories Agency, Woodham Lane, Weybridge, KT15 3NB, UK; amie.adkin@ahvla.gsi.gov.uk. has been greatly reduced. For BSE this has been achieved by stringent, long-term control measures and surveillance; indeed, the disease has almost disappeared. A voluntary program of genetic selection of breeding stock has reduced the prevalence of classical scrapie. However, until complete eradication, safeguards are still required to ensure that prion diseases are not recycled with animal by-product or waste disposal processing. Wastewater derived from premises handling and removing those parts of cattle and sheep carcases defined as specified risk material (SRM) can be applied to pasture land (land grazed by farm animals or land cropped for forage) in accordance with Annex II of Regulation (EC) 
No. 1774/2002, herein referred to as the Animal ByProducts (ABP) Regulation. ${ }^{(1)}$

Facilities that handle SRM include 251 licensed abattoirs $(A B)$ where healthy livestock are slaughtered. ${ }^{(2)}$ There are 61 licensed intermediate plants (INT) that collect fallen stock from farms and, where a valid license is held, carry out testing for TSE. Collection centers $(C C N)$, numbering 190 licensed facilities, do not test for TSEs, but are licensed to remove flesh to feed dogs (kennels) and zoo animals from animals that are certified not to contain any medication residues. The SRM from each of these facilities may be sent to rendering for disposal. Currently, there are eight rendering $(R E N)$ facilities accepting ruminant Category 1 and fallen stock in Great Britain (GB). The rendering process employed at these facilities produces Category 1 meat and bone meal (MBM) and tallow. The tallow is currently used as a fuel source, together with a significant proportion of the MBM, with the remainder sent to large incinerators $(I N C)$ or for energy production. There were $280 \mathrm{li}$ censed incinerators in GB in 2010, the majority of which are relatively small in scale $(S I N)$, owned by groups incinerating a range of waste materials. These include crematoria that handle pets and waste from $I N T$ plants and $C C N$ and veterinary center incinerators. From a survey conducted, only 10-12 large incinerators were licensed to process Category 1 materials and fallen stock.

Within the ABP Regulations, there is a requirement for filtration of all wastewater from SRM handling facilities through a 6-mm trap prior to any treatment and direct spreading to land. These regulations aim to address the environmental impact of spreading wastewater but do not specifically consider the animal health impacts. Several previous risk assessments have investigated the risk of BSE associated with abattoir effluents in Europe, ${ }^{(3,4)}$ Japan, ${ }^{(5)}$ and Australia ${ }^{(6)}$ and for renderer and incinerator effluent in the United Kingdom. ${ }^{(7-9)}$ However, the prevalence of certain TSEs (BSE in cattle and classical scrapie in sheep) has been steadily declining in recent years, and with considerable changes in the structure of SRM-handling industries in GB, a reappraisal of the TSE risk posed by wastewater is required.

This article, informed by the outputs of an accompanying paper, presents an analysis that was undertaken to assess the risk of livestock becoming infected with a TSE disease from wastewater that has been directly spread onto pasture land, both with and without treatment by filtration in accordance with the
ABP Regulations. The results from this assessment will be used to inform policy decisions in this area.

\section{METHODS}

\subsection{Model Overview}

The output of the quantitative risk assessment is an estimate of the annual number of potential new BSE infections in cattle and scrapie (classical and atypical) infections in sheep originating from the spread of wastewater derived from SRM-handling facilities. The model includes uncertain and variable parameters, which were simulated using the software package @Risk (๑Palisade) Version 5.0, an add-on package within Microsoft Excel (๑Microsoft). Convergence of all distributions was monitored, with the model being run for 200,000 iterations; this value ensured full convergence. The results presented follow the standard form of the arithmetic mean and the 5th and 95th percentile values. A multivariate stepwise regression analysis was used to calculate linear regression or sensitivity values for each input parameter in the model, which was represented by a probability distribution. This method is preferred for large numbers of input parameters, as all values that provide an insignificant contribution are removed from the analysis. In addition to this sensitivity analysis, the impact of uncertainty associated with specific key parameters was investigated. Selected scenarios were run to investigate the effect on the number of new TSE infections as predicted by the risk assessment. In these scenarios, parameters relating to (1) the effectiveness of trap, (2) the amount of wastewater produced, and (3) the proportion of wastewater spread on pasture were modified.

The scope of the risk assessment is wastewater derived from facilities that handle high-risk materials denoted as Category 1 SRM. To estimate the risk, we considered tissues designated as SRM, that have been removed from slaughtered cattle and sheep, entire bodies of dead animals containing SRM at the time of disposal, and the material removed from the drains from SRM handling facilities. SRM in cattle and sheep are those tissue types listed as highrisk tissues, which are required to be removed from animals and disposed of appropriately. ${ }^{(10)}$ Although it was assumed that there are some unintentional losses of SRM to the floor and wastewater at facilities, intentional illegal behavior was not included. Figure 1 gives an overview of the model and parameters, estimates for which are provided in Table I 


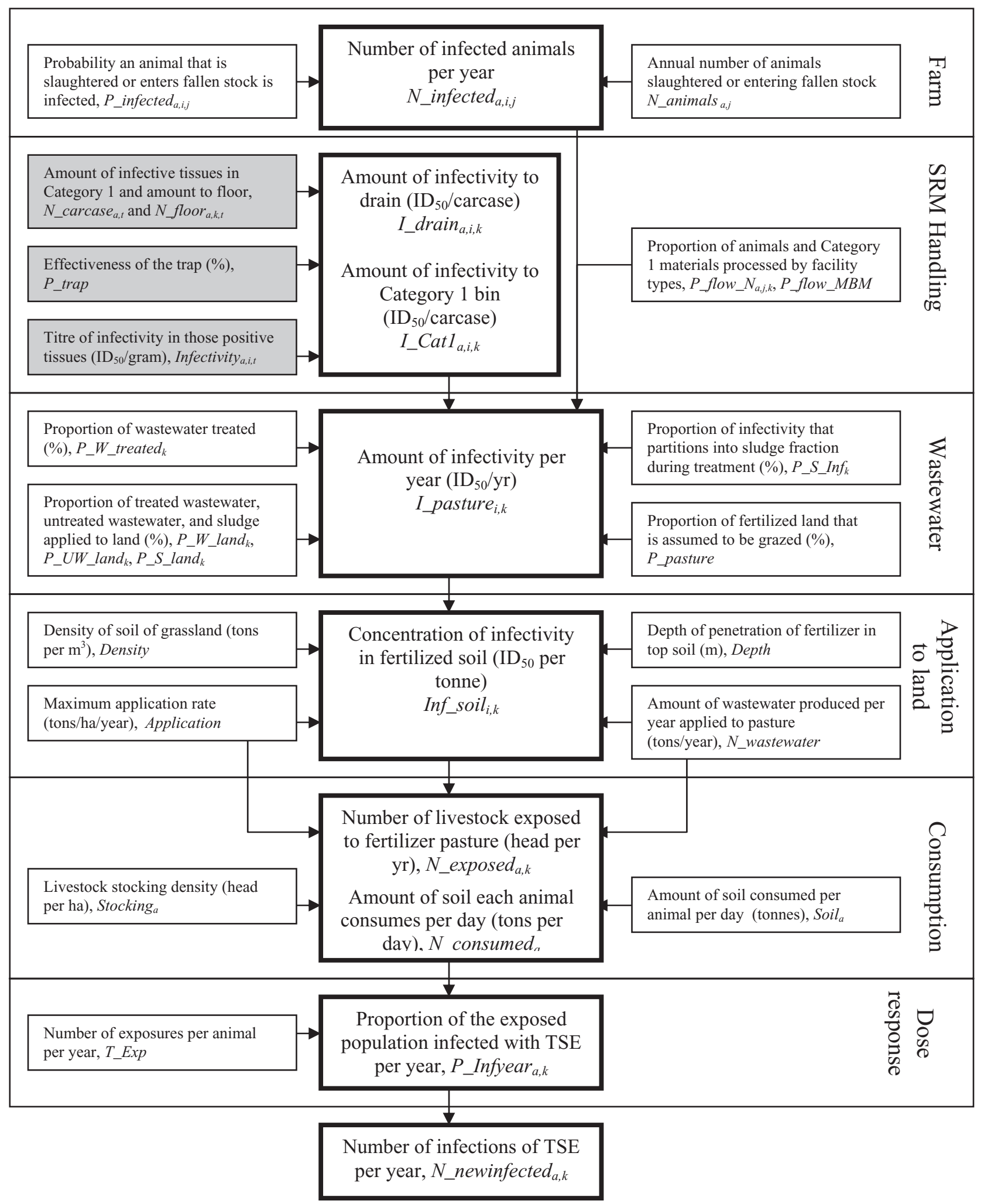

Fig. 1. Diagrammatic representation of the modules and parameters within the risk assessment, where subscripts denote animal group $a \in$ $\{C, S, l\}$, infectious tissue type $t \in\{1$ to 14$\}$, disease $i \in\{b s e, s c$, at $\}$, exit stream $j \in\{H S, F S\}$, facility type $k \in\{A B, I N T, C C N, R E N, S I N$, $I N C\}$. Shaded parameters indicate those described in the accompanying paper. 
Table I. Parameter Descriptions and Values Within the Risk Assessment

\begin{tabular}{|c|c|c|c|c|}
\hline Parameter & Symbol & Value & Unit & Reference \\
\hline \multicolumn{5}{|l|}{ Farm } \\
\hline $\begin{array}{l}\text { Probability a cow slaughtered at } \\
\text { abattoir is infected with BSE and is } \\
\text { in the last } 12 \text { months of the } \\
\text { incubation period }\end{array}$ & $P_{\text {_infected }}$, bse,$H S$ & $\begin{array}{l}\text { Betapert }\left(3.9 \times 10^{-7}\right. \\
\quad 1.4 \times 10^{-6}, 2.2 \times \\
\left.10^{-6}\right)\end{array}$ & $\%$ & $\begin{array}{l}\text { 11; Updated by } \\
\text { Arnold, personal } \\
\text { communication } \\
2010\end{array}$ \\
\hline $\begin{array}{l}\text { Probability a cow enters fallen stock } \\
\text { and is infected with BSE and is in } \\
\text { the last } 12 \text { months of the incubation } \\
\text { period }\end{array}$ & $P_{-}$infected ${ }_{C, b s e, F S}$ & $\begin{array}{l}\text { Betapert }\left(3.3 \times 10^{-6}\right. \\
\quad 4.4 \times 10^{-6}, 1.8 \times \\
\left.10^{-5}\right)\end{array}$ & $\%$ & $\begin{array}{l}\text { 11; Updated by } \\
\text { Arnold, personal } \\
\text { communication } \\
2010\end{array}$ \\
\hline $\begin{array}{l}\text { Probability a sheep/lamb slaughtered } \\
\text { at abattoir is infected with classical } \\
\text { scrapie }\end{array}$ & $\begin{array}{l}\text { P_infected } \\
\quad \text { for } a=S, l, H S\end{array}$ & $\begin{array}{l}\text { Betapert }\left(0,9.0 \times 10^{-4}\right. \\
\left.\quad 4.2 \times 10^{-3}\right)\end{array}$ & $\%$ & 13 \\
\hline $\begin{array}{l}\text { Probability a sheep/lamb entering } \\
\text { fallen stock is infected with classical } \\
\text { scrapie }\end{array}$ & $\begin{array}{l}\text { P_infected } \\
\quad \text { for } a=S, l, F S\end{array}$ & 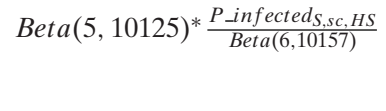 & $\%$ & 13 \\
\hline $\begin{array}{l}\text { Probability a sheep/lamb slaughtered } \\
\text { at abattoir is infected with atypical } \\
\text { scrapie }\end{array}$ & $\begin{array}{l}\text { P_infected } \\
\quad \text { for } a=S, l, H S\end{array}$ & $\begin{array}{l}\text { Betapert }\left(3.7 \times 10^{-4}\right. \\
\quad 2.4 \times 10^{-3}, 6.6 \times \\
\left.10^{-3}\right)\end{array}$ & $\%$ & 13 \\
\hline $\begin{array}{l}\text { Probability a sheep/lamb entering } \\
\text { fallen stock is infected with atypical } \\
\text { scrapie }\end{array}$ & $\begin{array}{l}\text { P_infected }_{a, a t, F S} \\
\quad \text { for } a=S, l\end{array}$ & 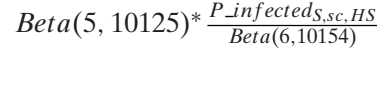 & $\%$ & 13 \\
\hline Number of cattle slaughtered & $N_{\text {_animals }}, H S$ & $2,301,868$ & Cattle & 12 \\
\hline Number of cattle entering fallen stock & $N_{\text {_animals }}, F S$ & 416,941 & Cattle & 12 \\
\hline Number of sheep slaughtered & $N \_$animals $_{S, H S}$ & $2,182,930$ & Sheep & 15 \\
\hline Number of sheep entering fallen stock & $N_{\text {_animals }}, F S$ & $\begin{array}{l}\text { Uniform (149287, } \\
\text { 447866) }\end{array}$ & Sheep & 15,16 \\
\hline Number of lambs slaughtered & $N_{\text {_animals }}, H S$ & $13,357,036$ & Lamb & 15 \\
\hline $\begin{array}{l}\text { Number of lambs entering fallen } \\
\text { stock }\end{array}$ & $N_{\_}$animals $_{L, F S}$ & $\begin{array}{l}\text { Uniform }(750046, \\
1734921)\end{array}$ & Lamb & 15,16 \\
\hline \multicolumn{5}{|l|}{ SRM handling } \\
\hline $\begin{array}{l}\text { Proportion of healthy slaughter flow } \\
\text { from abattoir to rendering }\end{array}$ & $P_{-}$flow_ $1_{a, H S, R E N}$ & $\begin{array}{l}\text { Betapert }(50 \%, 80 \% \\
\quad 90 \%)\end{array}$ & $\%$ & $12,17,18,41$ \\
\hline $\begin{array}{l}\text { Proportion of healthy slaughter flow } \\
\text { from abattoir to incineration }\end{array}$ & $P_{-}$flow_ $1_{a, H S, I N C}$ & 1- P_flow_1 $1_{a, H S, R E N}$ & $\%$ & \\
\hline $\begin{array}{l}\text { Proportion of fallen stock flow from } \\
\text { farm to collection center }\end{array}$ & $P_{-}$flow_ $1_{a, F S, C N N}$ & $\begin{array}{c}a=C: \text { Betapert }(10 \%, \\
20 \%, 30 \%) \\
a=S: \text { Betapert }(10 \%, \\
20 \%, 30 \%) \\
a=l: \text { Betapert }(5 \%, \\
15 \%, 20 \%)\end{array}$ & $\%$ & \\
\hline $\begin{array}{l}\text { Proportion of fallen stock flow from } \\
\text { farm to intermediate }\end{array}$ & $P_{-}$flow_1 $1_{a, F S, I N T}$ & $\begin{array}{l}a=C: \text { Betapert }(20 \%, \\
25 \%, 30 \%) \\
a=S: \text { Betapert }(10 \%, \\
15 \%, 20 \%) \\
a=l: \text { Uniform }(5 \%, \\
10 \%)\end{array}$ & $\%$ & \\
\hline $\begin{array}{l}\text { Proportion of fallen stock flow from } \\
\text { farm to rendering }\end{array}$ & $P$ flow_ $1_{a, F S, R E N}$ & $\begin{array}{l}\text { Betapert }(20 \%, 40 \% \text {, } \\
50 \%)\end{array}$ & $\%$ & \\
\hline $\begin{array}{l}\text { Proportion of fallen stock flow from } \\
\text { farm to incinerator }\end{array}$ & $P_{f}$ flow_ $1_{a, F S, I N C}$ & $\begin{aligned} \text { 1- } & \left(P_{-} \text {flow_1 } 1_{a, F S, C N N}+\right. \\
& P_{-} \text {flow_1 } 1_{a, F S, I N T}+ \\
& \left.P_{-} \text {flow_1 } 1_{a, F S, R E N}\right)\end{aligned}$ & $\%$ & \\
\hline $\begin{array}{l}\text { Proportion of fallen stock flow from } \\
\text { intermediate to collection center }\end{array}$ & $P_{f}$ flow_ $2_{a, F S, C C N}$ & $\begin{array}{c}a=C: \text { Betapert }(10 \%, \\
20 \%, 45 \%) \\
a=S: \text { Betapert } \\
(7 \%, 15 \%, 40 \%) \\
a=l: \text { Betapert }(5 \%, \\
15 \%, 40 \%)\end{array}$ & $\%$ & \\
\hline
\end{tabular}


Table I (Continued)

\begin{tabular}{|c|c|c|c|c|}
\hline Parameter & Symbol & Value & Unit & Reference \\
\hline $\begin{array}{l}\text { Proportion of fallen stock flow from } \\
\text { intermediate to rendering }\end{array}$ & $P_{-}$flow_ $2_{a, F S, R E N}$ & $\begin{array}{l}\text { Betapert }(40 \%, 50 \% \text {, } \\
\quad 75 \%)\end{array}$ & $\%$ & \\
\hline $\begin{array}{l}\text { Proportion of fallen stock flow from } \\
\text { intermediate to incineration }\end{array}$ & $P_{\text {flow }} 2_{a, F S, I N C}$ & $\begin{aligned} \text { 1- } & \left(P_{-} \text {flow } 22_{a, F S, C C N}+\right. \\
& \left.P_{-} \text {flow_2 } 2_{a, F S, R E N}\right)\end{aligned}$ & $\%$ & \\
\hline $\begin{array}{l}\text { Proportion of fallen stock flow from } \\
\text { collection center to renderer }\end{array}$ & $P_{-}$flow_ $3_{a, F S, R E N}$ & $\begin{array}{l}a=C: \text { Uniform }(70 \%, \\
95 \%) \\
a=S: \text { Uniform }(60 \%, \\
92 \%) \\
a=l: \text { Uniform }(60 \%, \\
92 \%)\end{array}$ & $\%$ & \\
\hline $\begin{array}{l}\text { Proportion of fallen stock flow from } \\
\text { collection center to incinerator }\end{array}$ & $P_{-}$flow_ $3_{a, F S, I N C}$ & 1- P_flow_3 $3 a, F S, R E N$ & $\%$ & \\
\hline $\begin{array}{l}\text { Proportion of MBM from rendering } \\
\text { to incineration }\end{array}$ & $P_{-}$flow_MBM & $83 \%$ & $\%$ & 17,18 \\
\hline \multicolumn{5}{|l|}{ Wastewater } \\
\hline $\begin{array}{l}\text { Proportion of wastewater from } \\
\text { abattoirs, intermediate plants, } \\
\text { collection centers, and small } \\
\text { incinerators that is treated }\end{array}$ & $\begin{array}{l}P_{-} W_{\_} \text {treated }_{k}, \text { for } \\
\quad k=A B, I N T \\
C C N, \text { SIN }\end{array}$ & Beta $(7+1,14-7+1)$ & $\%$ & 42 \\
\hline $\begin{array}{l}\text { Proportion of wastewater from } \\
\text { rendering and large incineration } \\
\text { facilities that is treated }\end{array}$ & $\begin{array}{r}P_{-} W_{\text {_treated }}, \text { for } \\
k=R E N, I N C\end{array}$ & $80 \%$ & $\%$ & 17,18 \\
\hline $\begin{array}{l}\text { Percentage of infectivity removed } \\
\text { from wastewater due to treatment } \\
\text { at abattoirs, intermediate plants, } \\
\text { collection centers, and small } \\
\text { incinerators }\end{array}$ & $\begin{array}{l}P_{-} S_{-} I n f_{k}, \text { for } k= \\
\quad A B, I N T, \\
\quad C C N, S I N\end{array}$ & Uniform $(30 \%, 99 \%)$ & $\%$ & $6,19,20$ \\
\hline $\begin{array}{l}\text { Percentage of infectivity removed } \\
\text { from wastewater due to treatment } \\
\text { at rendering and large incineration } \\
\text { facilities }\end{array}$ & $\begin{array}{l}P_{-} S_{-} I n f_{k}, \text { for } k= \\
\text { REN, INC }\end{array}$ & Uniform $(99 \%, 99.4 \%)$ & $\%$ & 20,21 \\
\hline $\begin{array}{l}\text { Proportion of untreated wastewater } \\
\text { to land from abattoirs, intermediate } \\
\text { plants, collection, and small } \\
\text { incinerators }\end{array}$ & $\begin{array}{l}P_{-} U W_{-} \text {land }_{k}, \text { for } \\
\quad k=A B, I N T \\
C C N, S I N\end{array}$ & $\operatorname{Beta}(2+1,10-2+1)$ & $\%$ & 42 \\
\hline $\begin{array}{l}\text { Proportion of untreated wastewater } \\
\text { to land from rendering and large } \\
\text { incineration facilities }\end{array}$ & $\begin{array}{r}P_{-} U W_{-} \text {land }_{k}, \text { for } \\
\quad k=R E N, I N C\end{array}$ & $3 \%$ & $\%$ & 17,18 \\
\hline $\begin{array}{l}\text { Proportion of treated wastewater to } \\
\text { land from abattoirs, intermediate } \\
\text { plants, collection, and small } \\
\text { incinerators }\end{array}$ & $\begin{array}{l}P_{-} W_{\text {_land }}, \text { for } k \\
\quad=A B, I N T \\
\quad C C N, S I N\end{array}$ & Beta $(2+1,4-2+1)$ & $\%$ & 42 \\
\hline $\begin{array}{l}\text { Proportion of treated wastewater to } \\
\text { land from rendering and large } \\
\text { incineration facilities }\end{array}$ & $\begin{array}{l}P_{-} W_{\text {_land }}, \text { for } k \\
\quad=R E N, I N C\end{array}$ & $25 \%$ & $\%$ & 17,18 \\
\hline $\begin{array}{l}\text { Proportion of wastewater sludge to } \\
\text { land from abattoirs, intermediate } \\
\text { plants, collection centers, and small } \\
\text { incinerators }\end{array}$ & $\begin{array}{l}P \_S_{\_} \text {land }_{k}, \text { for } k \\
\quad=A B, I N T \\
\quad C C N, \text { SIN }\end{array}$ & $\operatorname{Beta}(6+1,6-6+1)$ & $\%$ & 42 \\
\hline $\begin{array}{l}\text { Proportion of wastewater sludge to } \\
\text { land from rendering and large } \\
\text { incineration facilities }\end{array}$ & $\begin{array}{l}\text { P_S_land } k, \text { for } k \\
\quad=R E N, I N C\end{array}$ & $41 \%$ & $\%$ & 17,18 \\
\hline Proportion of land that is grazed & P_pasture & $40 \%$ & $\%$ & 22 \\
\hline
\end{tabular}


Table I (Continued)

\begin{tabular}{|c|c|c|c|c|}
\hline Parameter & Symbol & Value & Unit & Reference \\
\hline \multicolumn{5}{|l|}{ Application to land } \\
\hline \multirow{7}{*}{$\begin{array}{l}\text { Amount of wastewater produced per } \\
\text { year }\end{array}$} & Wastewater $_{A B}$ & $3 \times 10^{7}$ & Tons per year & $15,17,18,41$ \\
\hline & Wastewater INT & $1 \times 10^{4}$ & & \\
\hline & Wastewater ${ }_{C C N}$ & $2 \times 10^{4}$ & & \\
\hline & Wastewater $_{\text {SIN }}$ & $4 \times 10^{4}$ & & \\
\hline & Wastewater REN $_{\text {R }}$ & $7 \times 10^{5}$ & & \\
\hline & Wastewater INC & $2 \times 10^{5}$ & & \\
\hline & & $\begin{array}{l}\text { Mean values shown as } \\
\text { production } \\
\text { dependent on carcase } \\
\text { number, which varies } \\
\text { by } N \_a n i m a l_{a, j}\end{array}$ & & \\
\hline Application rate & Application & 0.025 & Tons $/ \mathrm{m}^{2} /$ year & 23 \\
\hline Depth of application & Depth & Uniform $(0,0.25)$ & $\mathrm{m}$ & $\begin{array}{l}\text { Animal Health, } \\
\text { personal } \\
\text { communication } \\
2010\end{array}$ \\
\hline Density of soil & Density & $\begin{array}{l}\text { Betapert }(0.88,0.9 \\
\quad 0.92)\end{array}$ & Tons $/ \mathrm{m}^{3}$ & 24 \\
\hline \multicolumn{5}{|l|}{ Consumption } \\
\hline \multirow[t]{2}{*}{$\begin{array}{l}\text { Amount of soil consumed per day per } \\
\text { animal }\end{array}$} & Soil $_{C}$ & $\begin{array}{l}\text { Uniform } \\
\qquad(0.23,0.38) / 1000\end{array}$ & Tons & 25,26 \\
\hline & Soil $_{S}$ & $\begin{array}{l}\text { Uniform } \\
\qquad(0.14,2.45) / 1000\end{array}$ & & \\
\hline \multirow[t]{2}{*}{$\begin{array}{l}\text { Stocking density of animals per } \\
\text { hectare per year }\end{array}$} & Stocking $_{C}$ & Uniform $(0.36,2)$ & Head per ha & $\begin{array}{l}\text { Scotland: } 28 ; \\
\text { England: } 29 ; \\
\text { UK: } 30,31,32\end{array}$ \\
\hline & Stocking $S$ & $\begin{array}{l}\text { Betapert } \\
\quad(3.33333,5.028595,14.1)\end{array}$ & & \\
\hline \multicolumn{5}{|l|}{ Dose response } \\
\hline Number of exposures per year & $T_{-} \operatorname{Exp}$ & 365 & & \\
\hline
\end{tabular}

of the supplementary materials. The model is split into six modules that track the TSE agent from the farm through to the wastewater being applied to land and the subsequent ingestion and infection of animals. Elements of the SRM-handling module, shown in gray in Fig. 1, are described in a separate paper.

\subsubsection{Farm Module}

The number of infected animals that die or are slaughtered each year is dependent on the prevalence of infection and the annual number of animals being processed via various exit streams. The term "exit stream" encompasses a general definition of streams of healthy slaughter animals (including emergency slaughter) at abattoir and fallen stock. Clinically suspect animals were not considered because the risk of infectivity entering wastewater has been considered negligible due to stringent disposal procedures. The use of exit streams is required as livestock in the different categories will have different TSE prevalences and will be diverted to different SRM-handling facilities. The estimated annual numbers of infected animals $\left(N \_\right.$infected $\left._{a, i, j}\right)$ per animal group $a \in\{C, S, l\}$, disease $i \in\{b s e, s c$, at $\}$, and exit stream $j \in\{H S, F S\}$ is given by Equation (1):

$$
N \_ \text {infected }_{a, i, j}=P \_ \text {infected }_{a, i, j}^{*} N \_ \text {animals }_{a, j},
$$

where $H S$ denotes animals slaughtered at abattoir and $F S$ denotes fallen stock; $b s e$ refers to BSE, $s c$ to classical scrapie, and $a t$ to atypical scrapie; $C$ refers to cattle, $S$ refers to sheep over one year of age, and $l$ denotes lambs (sheep less than one year of age). Sheep were divided into these two age groups because SRM controls are different for the two groups. For each animal group, disease, and exit stream combination, 
$P_{-}$infected $_{a, i, j}$ denotes the probability that an individual animal is infected (i.e., prevalence of infection), and $N_{-}$animals $_{a, j}$ the annual number of animals.

In relation to prevalence, for BSE in cattle it was assumed that only cattle in the last 12 months of the incubation period will harbor significant levels of infectivity. This is a very pessimistic assumption as infectivity increases significantly over this period from very low to high in the central nervous system. The prevalence of infected cattle in the last 12 months of the incubation period has been previously investigated $^{(11)}$ and was updated using BSE surveillance data up to 2009 (Arnold, personal communication 2010). The uncertainty associated with the mean prevalence estimates was described using a Betapert distribution for each exit stream (see Table I). The numbers of cattle slaughtered/dead in 2008 in the healthy slaughter (including emergency slaughter) and fallen stock streams were derived from data held by the British Cattle Movement Service (BCMS). ${ }^{(12)}$

The mean infection prevalence and 5th and 95th percentiles for classical scrapie in the healthy slaughter stream has been estimated previously, ${ }^{(13)}$ with values represented in the risk assessment by a Betapert distribution. In the absence of infection prevalence estimates for the fallen stock stream, case data were used (with a Beta distribution to describe the prevalence of cases) multiplied by the ratio of estimated healthy slaughter infection prevalence divided by healthy slaughter prevalence of cases (refer to Table I).

There are few data for atypical scrapie cases. In the absence of further information, the Abattoir Survey was used to estimate the prevalence of atypical scrapie. A number of key assumptions were applied when using these data: (1) the incubation period of atypical scrapie is the same as that estimated for classical scrapie (atypical scrapie is known to have a longer incubation period); (2) the survivability of sheep infected with atypical scrapie is the same as for classical scrapie; and (3) the sensitivity of the test for atypical scrapie is the same as for classical scrapie. As with classical scrapie, a ratio between prevalence of infection and prevalence of cases was calculated and used to modify the prevalence estimate for fallen stock animals. It has been suggested that classical and atypical scrapie can coexist within the same host. ${ }^{(14)}$ Therefore, it was assumed that all lambs and sheep entering the healthy slaughter and fallen stock streams could potentially be infected with both types of scrapie.
The total number of lambs and sheep entering the healthy slaughter stream is recorded by Defra statistics (standing population). There is no centralized recording of those sheep entering the fallen stock stream. Previously, estimates of the number of sheep dying on farm per year have been made by multiplying the percentage mortalities of sheep by the standing population. ${ }^{(16)}$ The number of lambs dying on farm has been estimated by multiplying the number of adult sheep by the lambing rate and an estimate of the percentage mortality of lambs. ${ }^{(15)}$ From discussions with stakeholders, not all fallen sheep and lambs are recorded as fallen stock and some burial of livestock still occurs. It was difficult to ascertain the exact proportion and it was assumed that $50-75 \%$ of fallen sheep enter the fallen stock stream. Using these data, a uniform distribution was used between 149,289 and 447,866 adult sheep to describe the uncertainty associated with the number of dead sheep entering fallen stock, and between 750,046 and $1,734,921$ for the number of lambs entering fallen stock.

\subsubsection{SRM-Handling Module}

SRM facilities, denoted by $k$, are defined as abattoirs $(A B)$, intermediate plants (INT), collection centers $(C C N)$, rendering $(R E N)$ facilities, small incineration plants $(S I N)$, and large incineration plants $(I N C)$. Thus, $k \in\{A B, I N T, C C N, R E N, S I N, I N C\}$. The proportion of healthy slaughter and fallen stock each year that are processed by each facility type was estimated and denoted by $P_{-}$flow $N_{a, j, k}$, where $N$ is the tier of the flow as shown in Figs. 2 and 3. For healthy slaughter $N=1$ since there is only a single tier. However, for fallen stock, $N=1,2,3$ as there are three tiers. These proportions are difficult to estimate directly as data are not collected centrally. Various data sources were used to estimate the proportion of the GB livestock handled by each facility type: (1) the national database of ABP facility licenses, (2) the number of livestock tests in total and by facility type (between 01/06/2008 and 31/05/2009), (3) expert opinion (animal health [AH], UK Rendering Association [UKRA], European Fat Processors and Rendering Association [EFPRA], Licensed Animal Slaughterers' \& Salvage Association [LASSA], Association of Independent Meat Suppliers [AIMS], and the British Meat Processors Association [BMPA]), and (4) surveys of all eight renderers ${ }^{(17)}$ and incinerators. ${ }^{(18)}$ The estimated most likely, minimum, and maximum values for each 


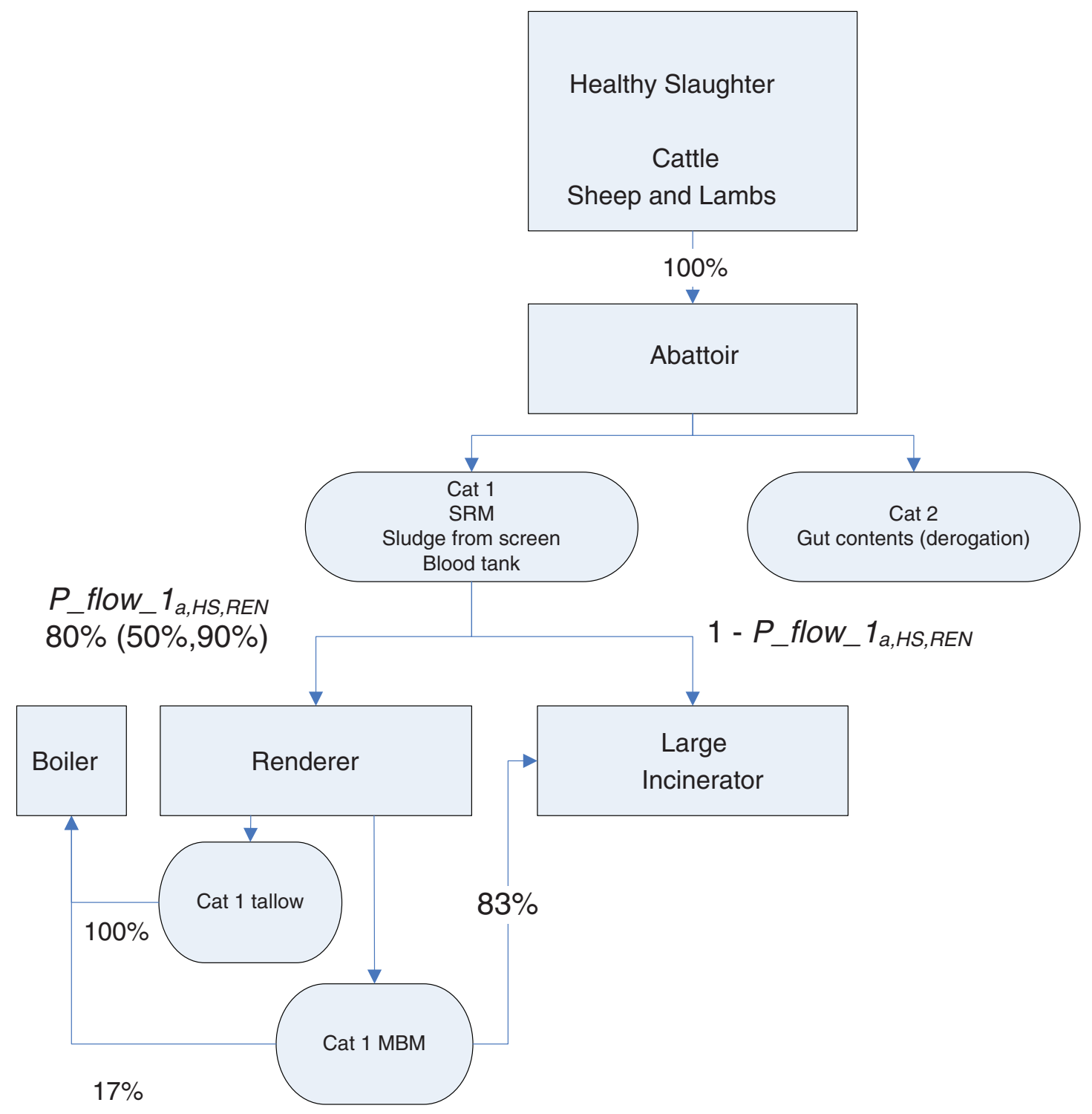

Fig. 2. Flow diagram of the process of SRM flow for healthy slaughter cattle, sheep, and lambs with estimated most likely rates of material flow (minimum and maximum).

animal population are shown in the flowcharts in Figs. 2 and 3 and in Table I. The uncertainty associated with the estimated flow of materials was represented by a uniform distribution in cases for which minimum and maximum values were available and a Betapert distribution in cases for which an estimate for the most likely value was also available.

Given the estimated proportion of livestock and associated Category 1 materials that entered each facility type per year, the SRM-handling module investigates the sequence of events for this infectivity to ultimately enter the drains, $I_{-}$drain $_{a, i, k}$, or be collected as Category 1 material for disposal, $I_{-}$Cat $_{a, i, k}$, as shown in Fig. 1. The amount of infectivity released from carcases to the floor of facilities is dependent on the TSE disease predilection for certain tissues within livestock, the particular animal host, and the type of activities conducted at each facility that release infectivity to the floor. Finally, the effect of the minimum 6-mm traps needs to be considered. Several of the parameters used in this module have a number of dependencies (facility type by animal population, TSE agent, and tissue type) and therefore 


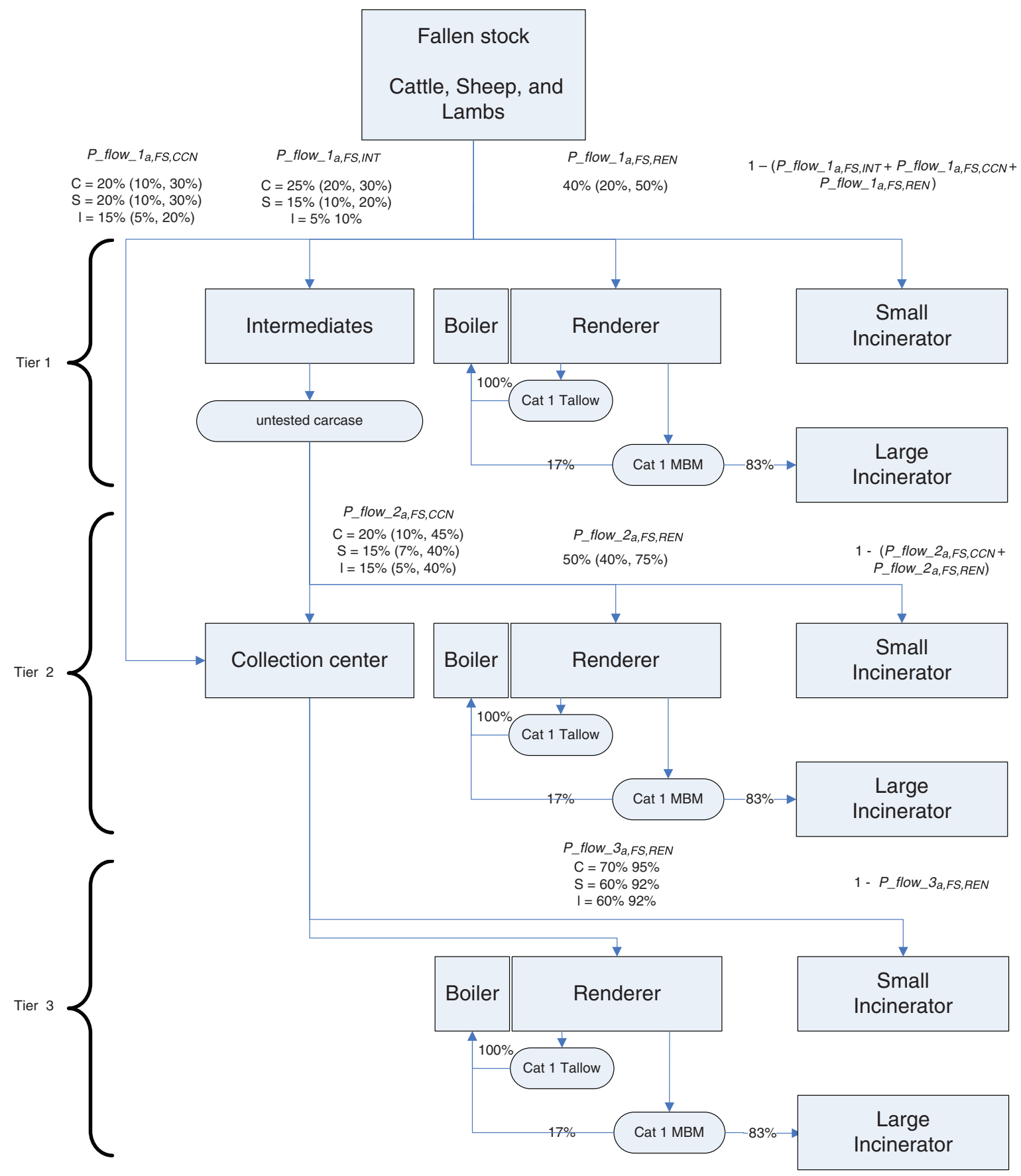

Fig. 3. Flow diagram of the process of SRM handling for fallen stock with estimated most likely rates of material flow (minimum and maximum), where $a \in\{C, S, l\}$.

these parameters have been estimated and presented separately in the accompanying paper, which presents results on a per infected carcase basis. Fig. 1 indicates those parameters that are described in the accompanying paper in shaded boxes.

\subsubsection{Wastewater Module}

The amount of infectivity to pasture from each facility type depends on the estimated number of infected animals/carcases processed through 
that facility type $\left(N_{-}\right.$infected $d_{a, i, j}^{*} P_{-}$flow $\left._{a, j, k}\right)$, the amount of infectivity that enters the drain per an$\mathrm{imal} /$ carcase $\left(I_{-} d\right.$ rain $\left._{a, i, k}\right)$, and facility-dependent probabilities of wastewater treatment and disposal routes. Wastewater may be treated, with infectivity separated into the treated wastewater fraction $\left(P_{-} W_{-}\right.$treated $\left._{k}^{*}\left(1-P_{-} S_{-} I n f_{k}\right)\right)$ or into the sludge fraction $\left(P_{-} W_{-}\right.$treated $\left.{ }_{k}^{*}\left(1-P_{-} S_{-} \operatorname{Inf} f_{k}\right)\right)$, or untreated $\left(1-P_{-} W_{-}\right.$treated $)$. The disposal route of interest is the proportion to land $\left(P \operatorname{land}_{k}\right)$ that is pasture ( $P_{-}$pasture). For each facility, the amount of infectivity spread on pasture $\left(\mathrm{ID}_{50}\right.$ per year), $I_{\text {_pasture }}, k$, was estimated by adding together the amount of infectivity from each wastewater type (untreated wastewater, wastewater that has been treated, and the sludge arising from such treatment) as shown in Equation (2):

$$
\begin{aligned}
\text { I_pasture }_{i, k} & =\sum_{a}\left(I_{-}\right. \text {Uwastewater } \\
& \left.+I_{\_} \text {wastewater }+I \_ \text {sludge }\right)_{a, i, k},
\end{aligned}
$$

where for untreated wastewater,

$$
\begin{aligned}
& I_{-} U_{w a s t e w a t e r}, i, k
\end{aligned}
$$

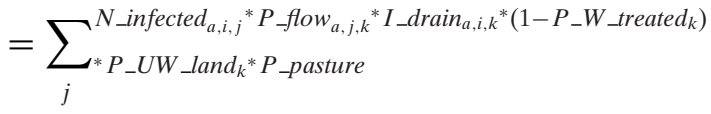

and for treated wastewater,

$$
\begin{aligned}
& I_{\_} \text {wastewater }{ }_{a, i, k}
\end{aligned}
$$

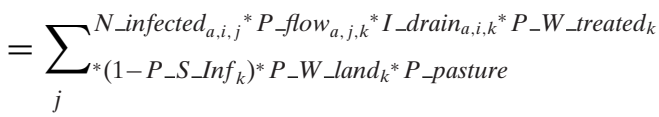

and for sludge arising from treated wastewater,

$$
\begin{aligned}
& I_{\text {s sludge }}{ }_{a, i, k}
\end{aligned}
$$

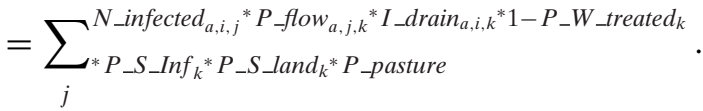

A number of different data sources were used to estimate the facility-dependent probabilities of wastewater treatment and disposal routes, provided in Table I, including published literature and two surveys. ${ }^{(17,18)}$ However, data were absent for INT, CCN, and small incinerators. These facilities were assumed to treat and disposal of wastewater in a similar manner to $A B$.

$P \_S_{\perp} \operatorname{Inf} f_{k}$ denotes the proportion of infectivity that partitions into the sludge fraction when wastewater is further processed. The use of biological treatments, dissolved-air-flotation (DAF) units, and screening differ in their ability to remove suspended solids from wastewater, and therefore any TSE agents that may associate with the sediment. ${ }^{(6)}$ However, the proportions of these treatments employed are not known for the different facility types, except for renderers, where a specific survey was performed. For small facility types, it was assumed that between $30 \%$ and $99 \%$ of infectivity will partition into the sludge phase when wastewater is further processed due to the range of treatments that are currently in use (assumption based on Refs. 6, 19, and 20) described using a uniform distribution. For renderers where treatment was undertaken, both biological treatment and DAF was applied, and it was assumed that large incinerators also employ such treatments. It was estimated that between $99 \%$ and $99.4 \%$ of infectivity partitions into the activated sludge solids during processing. ${ }^{(20,21)}$ It was assumed that there is no loss of infectivity during any consequent treatments of the sludge, for example, anaerobic digestion. $^{(4,20)}$

With no further information on the type of land to which the wastewater is applied, the proportion assumed to be grazed, P pasture, was set equal to the national proportion of grassland fertilized from the total area of grassland and crops fertilized, estimated to be $40 \%$. $^{(22)}$

\subsubsection{Application to Land Module}

The concentration of infectivity in soil where wastewater has been applied $\left(\mathrm{ID}_{50}\right.$ per ton soil), Infsoil $i, k$, is dependent on the estimated concentration of infectivity in wastewater (I_pasture $_{i, k}$ $\left./ N_{\text {_wastewater }}{ }_{k}\right)$, the application rate (tons $\left./ \mathrm{m}^{2}\right)$, density (tons $/ \mathrm{m}^{3}$ ), and depth of application (m) as shown by Equation (3):

$$
\begin{aligned}
& \text { Inf_soil }{ }_{i, k}= \\
& \left(\frac{\text { I_pasture }_{i, k}{ }^{*} \text { Application }}{N_{\text {_wastewater }} * \text { Ap }^{*} 10,000 * \text { Depth }^{*} \text { Density }}\right),
\end{aligned}
$$

where $N_{-}$wastewater $_{k}$ denotes the total amount of wastewater produced per year that is destined for pasture, as shown in Equation (4):

$$
\begin{aligned}
& N_{-} \text {wastewater }_{k}= \\
& \text { (Wastewater }_{k}^{*} P \text { pasture }{ }^{*}
\end{aligned}
$$

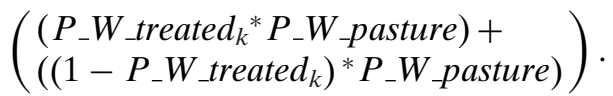


Estimates for total wastewater production are shown in Table I. Estimates for AB, Wastewater $_{A B}$, are based on the numbers of carcases processed, with $1,000 \mathrm{~L}$ per carcase used by large facilities processing $>150$ carcases per day, and 2,000 L per carcase used by $A B$ below this threshold (adapted from abattoir throughput data and discussions with $A B$ ). INT, $C C N$, and small incinerators are estimated to use less washing down water, with approximately $10-100 \mathrm{~L}$ per carcase (LASSA, personal communication 2009). Renderers were asked directly for water consumption data and it was assumed that large incinerators use similar amounts of water based on input weights as renderers. ${ }^{(17,18)}$ From a review of the literature, the application rate of wastewater to pasture, Application, is extremely variable and is dependent on the amount of nitrogen in the soil and wastewater as well as potential contaminants that may be present in the effluent. The maximum rate of application was estimated to be 0.025 tons $/ \mathrm{m}^{3} /$ year. ${ }^{(23)}$ The depth of application, Depth, will vary, with some wastewater surface spread and sludge fractions injected to depths of $22-25 \mathrm{~cm}$. Therefore, the depth of application was estimated to be between $0 \mathrm{~m}$ and $0.25 \mathrm{~m}$, described in the model using a uniform distribution. The density of soil, Density, was estimated as between 0.88 tons $/ \mathrm{m}^{3}$ and 0.92 tons $/ \mathrm{m}^{3}$, with a most likely value of 0.9 tons $/ \mathrm{m}^{3}$. ${ }^{24)}$

\subsubsection{Consumption by Livestock Module}

To estimate the number of infected livestock per year, the number of livestock exposed to the fertilized pasture and amount of infectivity consumed per day was estimated using Equation (5):

$$
\begin{aligned}
& N_{\_} \text {consumed }_{a, i, k}=\text { Soil }_{a}{ }^{*} \text { Inf_soil }{ }_{i, k} \text {, } \\
& N_{-} \text {exposed }_{a, k}=\frac{N_{-} \text {wastewater }_{k}}{\text { Application }^{*} \text { Stocking }_{a}},
\end{aligned}
$$

where Soil $_{a}$ is the amount of soil consumed per day by livestock species and has been estimated based on the percentage of consumed dry matter as soil and average dry matter intake. ${ }^{(25,26)}$ It was assumed that lambs consume the same amount of soil as adult sheep, which is acknowledged as overestimating risk. The assumption was made that any grazing cattle and sheep will have access to pasture all year round and that the full soil depth of fertilizer, that is, to a maximum of $25 \mathrm{~cm}$. This was considered a worst-case pre- caution as it is acknowledged to be unrealistic but has been used inherently in previous risk assessments. ${ }^{(27)}$

Descriptions of stocking density for livestock, Stocking ${ }_{a}$, vary in the literature. Ranges of 0.36-2.0 adult cattle per hectare (Scotland: Ref. 28; England: Ref. 29), and a maximum of 14.1 sheep per hectare were found (UK: Ref. 30). In a postal survey of sheep farmers in GB in November 2002 the midpoint stocking density of sheep $>1$ year old was found to be 5.02 adult sheep per hectare. ${ }^{(31)}$ The lower European livestock density index for sheep to keep grassland in good condition equates to 3.3 sheep per hectare. ${ }^{(32)}$ These data are used in the risk assessment as shown in Table I. It was assumed that the stocking density for lambs is the same as the stocking density for sheep.

\subsection{Dose Response and Risk Estimate}

A dose-response model was used to determine the probability of infection occurring as a result of exposure to a given dose of a pathogen. Research conducted with scrapie-adapted strains seems to indicate that, as yet, there is no clear consensus as to whether TSE doses act independently, cumulatively, or interact in succession. ${ }^{(33-35)}$ Further, in regards to hamster and mouse experiments, ${ }^{(33,35)}$ it is uncertain whether these results would apply to all TSE agents given the differences in species and agents. It is assumed that the proportion of a population that becomes infected from a single dose, $P_{\text {Infday }}, k$, can be estimated using the following exponential doseresponse equation: ${ }^{(36)}$

$$
P_{-} \text {Infda }_{a, k}=1-e^{\left(-r^{*} N_{-} \text {consumed }_{a, i, k}\right)},
$$

where $r$ is the pathogen infectivity constant. This model assumes that each infectious particle's action is independent, that is, the probability of infection by each single agent is independent of the size of the dose. When P_Infday ${ }_{a, k}=0.5$, that is, $50 \%$ of an exposed population becomes infected $\left(\mathrm{ID}_{50}\right)$, and $N_{-}$consumed $_{a, i, k}=1$, then $-r=\operatorname{Ln}(0.5)$. Substituting into Equation (6):

$$
P_{-} \text {Infday } y_{a, k}=1-e^{\left({\operatorname{Ln}(0.5)^{*}} N_{-} \text {consumed }_{a, i, k .}\right)} \text {. }
$$

For both cattle and sheep the period of exposure is not limited to a single dose as successive doses are likely to be consumed over time as animals graze the land. An annual risk of infection from T_exp exposures per year, assumed to be 365 days, to a pathogen dose was estimated by 
Equation (8):

$$
P \text { Infyear }_{a, k}=1-\left[1-e^{\left(\operatorname{In}(0.5)^{*} P \_i n f d a y_{a, k}\right)}\right]^{T \_\exp } .
$$

Combining with Equation (7):

$$
P \text { Infyear }_{a, k}=1-\left[1-e^{\left(\operatorname{In}(0.5)^{*} P \_i n f d a y_{a, k}\right)}\right]^{T \_\exp },
$$

where $T \cdot \exp$ is the number of exposures per year, assumed to be 365 days. Finally, the mean number of livestock infected per year is estimated using Equation (10):

$$
N \_n e w i n f e c t e d_{a, k}=N \_ \text {exposed }_{a, k}{ }^{*} P \_ \text {infyear }{ }_{a, k} \text {. }
$$

\section{RESULTS}

The results indicate the number of new TSE infections arising per year due to the application of wastewater to pasture would be low. The mean values are low for each TSE disease considered, with $0.001\left(1.8 \times 10^{-6}, 0.0013\right)$ new infections of BSE in cattle per year, $0.033(0.0004,0.064)$ new infections of classical scrapie in sheep per year, and 0.030 (0.0003, 0.061 ) new infections of atypical scrapie per year. Such results can be represented as the number of years between one new infection if it is assumed that there is no change over time and equal intervals between infections. Using this assumption, there is an estimated mean of one infection every 1,000 years for BSE in cattle $(769,555,556)$, and one infection every 30 years $(16,2,500)$ and 33 years $(16,3,333)$ for classical and atypical scrapie in sheep, assuming that values and assumptions used in the risk assessment remain constant.

The contribution to the total number of new TSE infections arising by facility type is given in Fig. 4. For BSE in cattle, the largest contributions are from $A B(35 \%)$ and $R E N$ facilities (22\%). Intermediates, $C C N$, and small incinerators contribute $13 \%, 11 \%$, and $15 \%$, respectively, with large incinerators contributing the least toward new BSE infections (4\%). The largest contributions for classical scrapie are from rendering (31\%), small incinerators $(30 \%)$, and $A B(23 \%)$. Intermediates, $C C N$, and large incinerators contribute only small amounts to the total infectivity with between $3 \%$ and $8 \%$. For atypical scrapie, the largest contributions are from small incinerators (34\%), rendering (31\%), and $A B(20 \%)$. The smallest contributions are from intermediates $(3 \%), C C N$ $(4 \%)$, and large incinerators (9\%).

The estimated numbers of BSE, classical scrapie, and atypical scrapie infections were also parti- tioned into each of the three wastewater types (untreated/treated wastewater and wastewater sludge). The mean percentage contribution of each wastewater type to the total amount of infectivity is shown in Fig. 5. It can be seen that the sludge fraction arising during wastewater treatment contributes the most amount of infectivity for BSE and scrapie diseases, with between $47 \%$ and $62 \%$ contribution to the total risk, respectively. Treated wastewater contributes the least on average, with an estimated $14-17 \%$ respective contribution to the total risk.

As shown by the range in brackets where $90 \%$ of the results are expected, the quantified uncertainty and variability associated with these estimates is large. From the sensitivity analysis the parameters with the greatest impact on the results are associated with variability of the depth of application of wastewater and with consumption of soil by livestock (Depth, Soil ${ }_{S}$ ), and uncertainty associated with disease characteristics of tissue infectivity and ID $_{50}$ conversion units presented in the accompanying paper (MaxCNS, BOunit, OOunit), which have been noted in previous TSE risk assessments. ${ }^{(37)}$ Finally, the parameter associated with the proportion of infectivity falling to the floor at $R E N$ facilities, $P_{-}$floor $_{a, i, R E N}$, described in the accompanying paper, was found to be influential. This parameter could be further enumerated by experimentation. However, the identified obstacles to such measurements identified in previous work ${ }^{(38)}$ would need to be considered when producing any experimental protocol.

\subsection{Scenario Testing}

Selected scenarios were run to investigate the effect on the estimated number of new TSE infections arising.

(1) The effectiveness of drain trap: The effectiveness of trap in the baseline scenario was represented in the model by $P_{-}$trap as between $80 \%$ and $90 \%$ based on estimates from the literature (refer to accompanying paper for further details). To investigate the impact of trap effectiveness on the number of new TSE infections, values of $0 \%, 25 \%, 50 \%$, and $75 \%$ retention of infectious material were simulated. The relationship between trap effectiveness and the mean number of new TSE infections is approximately linear. At $0 \%$ trap effectiveness, the estimated number of new TSE infections is shown in Table II. 


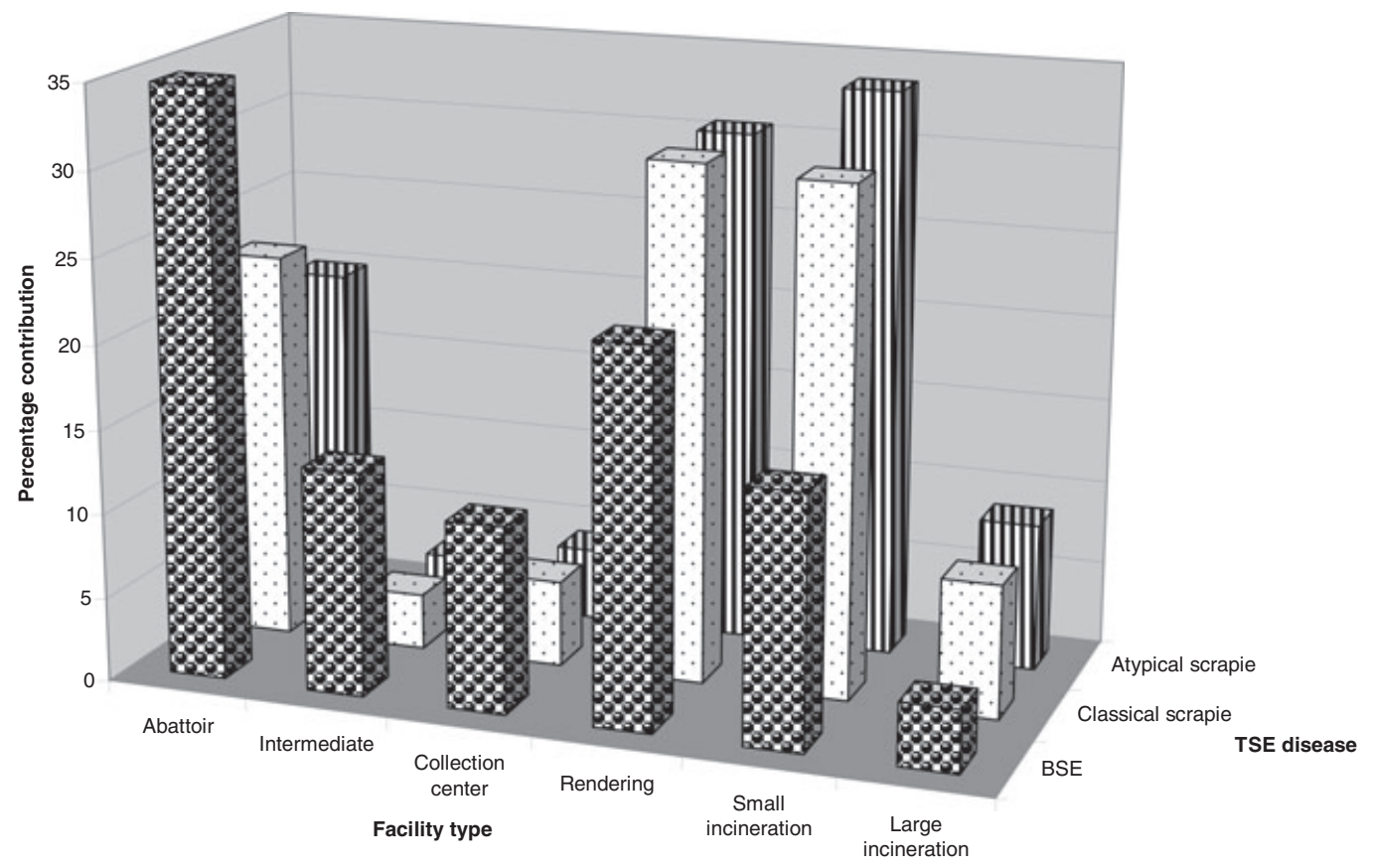

Fig. 4. Mean percentage contribution to total infectivity by facility type.

Fig. 5. Mean percentage contribution to total infectivity by wastewater type.

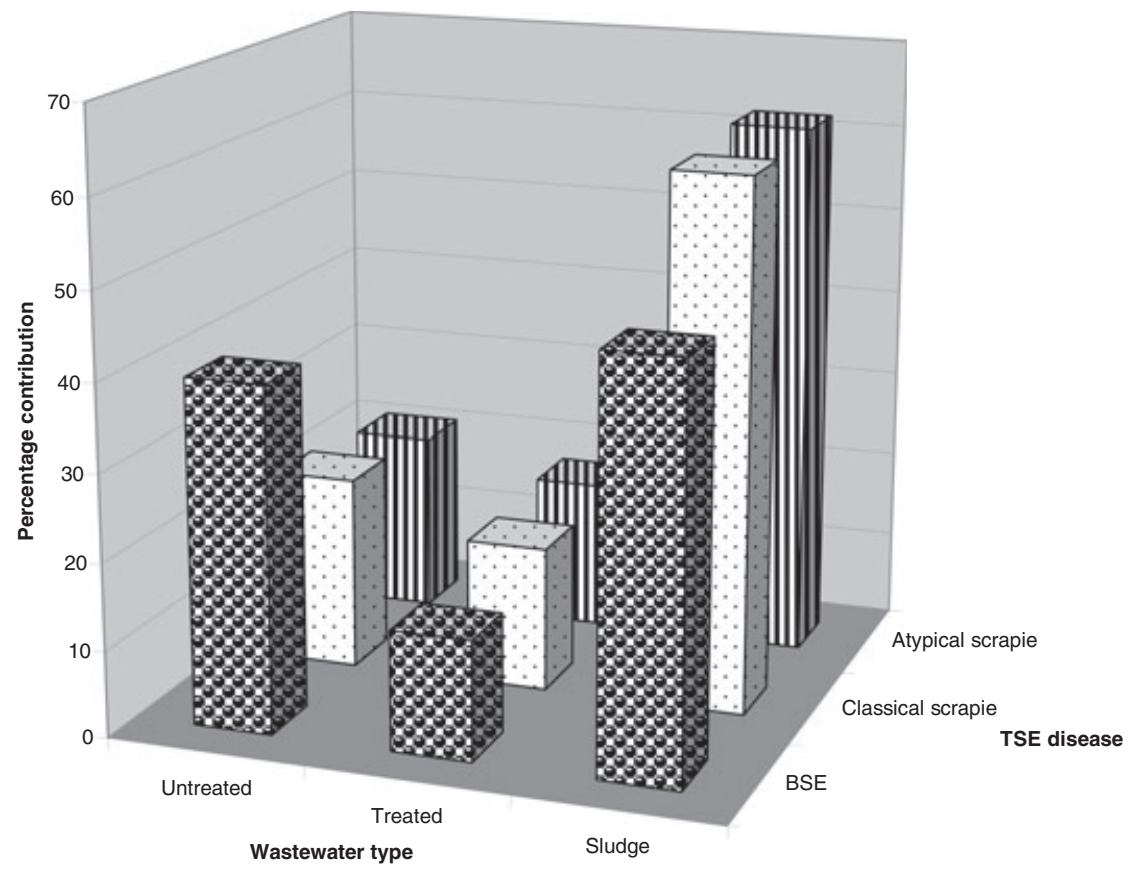

(2) The amount of wastewater produced: The amount of wastewater produced at each facility was estimated using industry data and expert opinion based on the number of carcases processed, with resulting values associated with considerable uncertainty bounds.
To investigate the impact of dramatic changes in wastewater production, the baseline figures were doubled and trebled. Neither scenario produced a significant change in the risk estimate in comparison with the baseline model. 
Table II. Estimated Results from Scenario Testing

\begin{tabular}{lcc}
\hline Scenario & $\begin{array}{c}\text { Scenario } \\
\text { Values }\end{array}$ & $\begin{array}{c}\text { Risk } \\
\text { Estimate }\end{array}$ \\
\hline $\begin{array}{l}\text { 1. Effectiveness } \\
\text { of trap }\end{array}$ & 0 & $\begin{array}{c}\text { BSE 0.007 }\left(1 \times 10^{-5},\right. \\
0.01) \\
\text { Classical scrapie 0.136 } \\
(0.002,0.27) \\
\text { Atypical scrapie } 0.121 \\
(0.001,0.24) \\
\text { No significant change in } \\
\text { mean results }\end{array}$ \\
$\begin{array}{l}\text { 2. Amount of } \\
\text { wastewater } \\
\text { produced } \\
\text { per year }\end{array}$ & Baseline $\times 2$ & \\
$\begin{array}{l}\text { 3. Proportion } \\
\text { of } \\
\text { wastewater } \\
\text { to pasture }\end{array}$ & Baseline $\times 1.75$ & $\begin{array}{c}\text { Mean results } \times 1.75 \\
\text { Mean results } \times 2.5\end{array}$ \\
\hline
\end{tabular}

(3) The proportion of wastewater to pasture: In the baseline model, $40 \%$ of all wastewater applied to land is assumed to be spread on pasture. The calculation of this figure was based on the proportion of fertilized land in GB that is composed of grassland and is a point estimate in the model. To investigate the impact of unquantified uncertainty associated with this parameter, the baseline figure was increased to $70 \%$ followed by $100 \%$ (all fertilized land is grazed). The relationship between the proportion of wastewater to pasture and the mean number of new TSE infections is approximately linear.

\section{DISCUSSION}

In this article, we have described the development and parameterization of a quantitative risk assessment to assess the risk of cattle and sheep becoming infected with a TSE disease from wastewater that has been directly spread onto pasture land. The contribution to the number of new TSE infections by facility type differs by TSE disease and for sheep and lambs. This is due to each disease having a different predilection for different tissue types, which vary in their probabilities of falling to floor in each facility type, and the different processing that may be applied to lambs as opposed to larger adult sheep. For BSE in cattle the main contributors are abattoir and rendering effluent, contributing $35 \%$ and $22 \%$ of the total number of new BSE infections. For TSEs in sheep, effluent from small incinerators and rendering are the major contributors (on average $32 \%$ and $31 \%$ of the total number of new classical scrapie and atypical scrapie infections). Such contributions are due to the volume of material flow through such facilities. It also needs to be remembered that an assumption was made that all facilities use a 6-mm trap before collection of wastewater, whereas many facilities, particularly the rendering industry, are known to use traps of $4 \mathrm{~mm}$ down to $1 \mathrm{~mm}$ that may retain more material. Therefore, this assumption is worst case.

Other pessimistic assumptions need to be highlighted. It is assumed that any grazing livestock will have access to pasture all year round and have access to the full soil depth of fertilizer, that is, to a maximum of $25 \mathrm{~cm}$. These assumptions are unrealistic as the majority of grazing livestock are likely to be housed with feed for several months of the year, and when grazing, a depth of $25 \mathrm{~cm}$ is unlikely to be realized. It is assumed that intentional illegal activities that may bypass controls do not occur. Due to the permanent structures in place, it is less likely that large-scale industries, such as rendering and large incinerators (which comprise a combined contribution to risk of $26 \%$ for BSE and $39 \%$ for sheep TSEs), can bypass built-in wastewater and drainage controls when compared to smaller more ad hoc operations such as INT, CCN, and small incinerators (which together contribute $39 \%$ for BSE and $40 \%$ for sheep TSEs to the risk estimate). Such facility types, together with smaller abattoir operations, are locations where illegal operations may occur and that contribute significantly to risk. For example, an abattoir operating illegally with no blood tank and no controls on wastewater could be illegally spreading such effluent direct to pasture. However, from discussions with licensing authorities, such occurrences are likely to be rare, although there are recorded incidents. Although current SRM controls are in place the amount of infectivity released by such rare events will still be small.

By varying the effectiveness of the trap from $0 \%$ to $75 \%$, the relationship between the trap retaining material and new infections was found to be approximately linear. When considering that the trap retains no material, the expected number of new infections increases approximately 6.5-fold for BSE and 4-fold for classical and atypical scrapie. When considering whether a $0 \%$ effective trap is the same as removing the trap, further investigation would be required. Additional supporting information would need to be collected to establish whether any operator behavioral changes may accompany the removal of the 
trap, for example, unconsciously would more material be allowed to fall to floor as there is no trap to lift and unblock when full?

The form of Equations (4) and (5) indicate that as more wastewater is produced, any infectivity present becomes more diluted. However, that same amount of infectivity is spread on more land, leading to more animals being exposed. Given that the doseresponse model does not have a lower bound value (that is infinitely divisible), changes in the amount of wastewater produced and applied to pasture have no effect on the number of new TSE infections.

The risk assessment is based on wastewater production and application to land over one year. However, effluent is applied each year and in areas where repeated applications are made there may be an accumulation of infectivity on those fields. TSE agents are associated with long-term environmental persistence. Seidel et al. found by western blotting a strong decrease in the amount of extractable scrapie prion protein after 29 months in sandy loam soil. However, it is unclear whether this is due to molecular decay of the protein or due to tight binding to soil particles. ${ }^{(39)}$ For one farm in Iceland, epidemiological investigation into an outbreak of scrapie established, with near certitude that the disease could not have been externally introduced and concluded that the agent may have persisted in an old sheep house for at least 16 years. ${ }^{(40)}$ Despite this, given the expected low numbers of BSE infected cattle and the random occurrence of disease among herds, it is unlikely, at the current time, that infected animals will be processed and any contaminated wastewater applied to the same location in successive years. However, for scrapie in sheep, accumulation is more likely if certain areas have repeated application of wastewater in successive years. To investigate this phenomenon in more detail a survey of the contractors that carry out wastewater collection and spreading would need to be completed, with details collected of the locations where wastewater is applied and frequency of application.

The risk assessment focuses on an industry in GB that is not well characterized in the literature and is subject to constant changes due to market demands. Therefore, the results are essentially a snapshot in time of a constantly evolving industry. During the facility visits undertaken and surveys conducted, the changing nature of the industry was highlighted. There have been significant recent reductions in the usage of small incinerators and the mothballing of several large-scale incinerators due to high fuel costs, and conversely a rise in the value of animal wastes to be used as a cofuel to produce energy. Given the limitations of published accounts, several areas of the risk assessment are based on expert opinion and assessors' assumptions based on viewing processes conducted. However, all significant parameters identified by the sensitivity analysis are based on data that were available from the literature and surveys conducted.

\section{CONCLUSIONS}

A quantitative risk assessment was developed to assess the risk of cattle and sheep becoming infected with a TSE disease from wastewater that has been directly spread onto pasture land. The key results indicate the number of new TSE infections arising from this practice would be low, with a mean of one infection every 1,000 years for BSE in cattle, one infection every 30 years for classical scrapie, and 33 years for atypical scrapie, assuming no change in conditions.

For BSE in cattle the main contributors are abattoir and rendering effluent and for TSEs in sheep, effluent from small incinerators and rendering are the major contributors. This is a reflection of the volume of carcase material and Category 1 material flow through such facilities.

\section{ACKNOWLEDGMENTS}

This risk assessment has been funded by the Department of Environment, Food and Rural Affairs (Defra). We express our gratitude for the numerous data providers identified in Table I.

\section{REFERENCES}

1. European Commission. Regulation (EC) $1774 / 2002$ of the European parliament and the council laying down health rules concerning animal by-products not intended for human consumption. Official Journal of the European Communities, 2002; L273:0001-0095.

2. Meat and Hygiene Service. Abattoir Throughput Database. 2009 for the time period September 2008 to August 2009. Food Standards Agency, Accessed January 22, 2010.

3. Det Norske Veritas. Overview of Risks from BSE via Environmental Pathways for the Environment Agency. Report for the Environment Agency, Bristol. Det Norske Veritas Ltd. London SE19DE. Ref C7243. June 1997.

4. Gale P, Stanfield G. Towards a quantitative risk assessment for BSE in sewage sludge. Journal of Applied Microbiology, 2001; 91(3):563-569.

5. Yamamoto T, Kobayashi S, Nishiguchi A, Nonaka T, Tsutsui T. Evaluation of bovine spongiform encephalopathy (BSE) infection risk of cattle via sewage sludge from wastewater treatment facilities in slaughterhouses in Japan. Journal of Veterinary Medical Science, 2006; 68(2):137-142. 
6. Quinn DT, Fabiansson SU. Risk assessment of abattoir effluent should BSE be found in cattle in Australia. A report prepared for the NHMRC Special Expert Committee on TSEs. Bureau of Rural Sciences, Kingston, June 2001.

7. Det Norske Veritas. Thruxted Mill Rendering Plant-Risk Assessment of Wastewater Disposal Options. Det Norske Veritas Ltd. London SE19DE. Ref C7175, January 1997.

8. Det Norske Veritas. Risk Assessment of SRM Incinerators. Prepared for the UK Ministry of Agriculture, Fisheries and Food. Det Norske Veritas Ltd. London SE19DE. Ref 1000089, March 2001.

9. Comer PJ, Spouge JR. Risk assessment of BSE infectivity in the environment from rendering of over thirty month scheme cattle. Journal of Risk Research, 1998; 1(4):281-293.

10. European Commission. Listing of Specified Risk Materials: A Scheme for Assessing Relative Risks to Man: Opinion of the Scientific Steering Committee Adopted on 9 December 1997, 1998. Available at: http://ec.europa.eu/ food/fs/sc/ssc/out22_en.pdf, Accessed January 2011.

11. Arnold M, Wilesmith JW. Modelling studies on BSE occurrence to assist in the review of the over 30 months rule in Great Britain. Proceedings of the Royal Society, 2003; 270:2141-2145.

12. British Cattle Movement Service. Cattle Tracing Service. Management Information Team. Rural Payments Agency. Reading. Available at: http://www.bcms.gov.uk/, Accessed December 2009

13. Ortiz-Pelaez A, Arnold M. Sheep Scrapie Surveillance 2008: Joint Descriptive Report for Great Britain. Centre for Epidemiology and Risk Analysis. Weybridge: Veterinary Laboratories Agency, December, 2009.

14. Mazza M, Iulini B, Vaccari G, Acutis PL, Martucci F, Esposito E, Peletto S, Barocci S, Chiappini B, Corona C, Barbieri I, Caramelli M, Agrimi U, Cassalone C, Nonno R. Co-existence of classical scrapie and Nor98 in a sheep from an Italian outbreak. Research in Veterinary Science, 2010; 88(3):478-485.

15. Department of Environment, Food and Rural Affairs. Defra Slaughter Statistics for 2009. Available at: http://www.defra.gov.uk/statistics/foodfarm/food/slaughter/, Accessed March, 2010.

16. Bansback B. Independent Review of the National Fallen Stock Scheme and Company. 13 April 2006. Available at: http://www.defra.gov.uk/foodfarm/byproducts/documents/ nfsco-review.pdf, Accessed January 2010.

17. Donaldson N. Survey of British Renderers. Centre for Risk Analysis and Epidemiology. Weybridge: Veterinary Laboratories Agency, February, 2010.

18. Donaldson N. British Category 1 and 2 Incinerators: Survey of Lead Animal Health Veterinary Officers. Centre for Risk Analysis and Epidemiology. Weybridge: Veterinary Laboratories Agency February, 2010.

19. Mittal GS. Treatment of wastewater from abattoirs before land application-A review. Bioresource Technology, 2006; 97(9):1119-1135.

20. Hinckley GT, Johnson CJ, Jacobson KJ, Bartholomay C, McMahon KD, McKenzie D, Aiken JM, Pedersen JA. Persistence of pathogenic prion protein during simulated wastewater treatment processes. Environmental Science and Technology, 2008; 42(14):5254-5259.

21. Gale P, Dee A, King P. Risk assessment for the disposal of treated rendering plant ruminant condensate to agricultural land. Report to the Ministry of Agriculture, Fisheries and Food, WRc Report No. CO 4937, June, 2000.

22. Department of Environment, Food and Rural Affairs. Agricultural Census for 2009. Available at: http://www.defra.gov. uk/evidence/statistics/foodfarm/landuselivestock/junesurvey/, Accessed February 2010.

23. Mittal GS. Regulations related to land-application of abattoir wastewater and residues. Agricultural Engineering Interna- tional: The CIGR Ejournal. Invited Overview No. 10. Vol. IX, 2007.

24. Engles C. The Effect of Grazing Intensity on Soil Bulk Density. Department of Civil Engineering, North Dakota State University, USA 1999. Available at: http://www.ag. ndsu.nodak.edu/streeter/99report/soil_bulk.htm, Accessed February 2010.

25. Peterson AD, Baumgardt BR, Long TA. Relationship between intake of some forage and feeding behaviour of sheep. Journal of Animal Science, 1974; 38(1):172-177. Available at: http://jas.fass.org/cgi/reprint/38/1/172.

26. Thornton I, Abrahams P. Soil ingestion-A major pathway of heavy materials into livestock grazing contaminated land. Science of the Total Environment, 1983; 28(1-3):287-294.

27. Cummins E, Adkin A. Exposure assessment of TSEs from the landspreading of meat and bone meal. Risk Analysis, 2007; 27(5):1179-1202.

28. Chadwick L. The Farm Management Handbook 2003/2004. Scottish Agricultural College, Scotland, 2003.

29. Meat and Livestock Commission. 2001 Beef Yearbook. Milton Keynes, UK: MLC Publications, 2001.

30. Meat and Livestock Commission. 2002 Sheep Yearbook. Milton Keynes, UK: MLC Publications, 2002.

31. McIntyre KM, Gubbins S, Kumar Sivam S, Baylis M. Flocklevel risk factors for scrapie in Great Britain: Analysis of a 2002 anonymous postal survey. BMC Veterinary Research, 2006; 2(25):1-7.

32. Jones PJ, Tranter RB. Modelling the impact of different policy scenarios on farm business management, land use and rural employment. University of Reading. Project Document No. 13. Workpackage No. 5, Report No. 02, June, 2007. Available at: http://www.relu.rdg.ac.uk/Working\%20Papers\% 20and\%20Reports/Doc13WP5Rep02LUAMPolicyScenarios. pdf, Accessed January 2011

33. Diringer H, Roehmel J, Beekes M. Effect of repeated oral infection of hamsters with scrapie. Journal of General Virology, 1998; 79:609-612.

34. Gravenor MB, Stallard N, Curnow R, McLean AR. Repeated challenge with prion disease: The risk of infection and impact on incubation period. Proceedings of the National Academy of Science, 2003; 100:10960-10965.

35. Jacquemot C, Cuche C, Dormont D, Lazarini F. High incidence of scrapie induced by repeated injections of subinfectious prion doses. Journal of Virology, 2005; 79:8904-8908.

36. Teunis PF, Havelaar AH. The Beta Poisson dose-response model is not a single-hit model. Risk Analysis, 2000; 20(4):513-520.

37. Adkin A, Nicholls V, Arnold M, Wells G, Matthews D. Estimating the impact on the food chain of changing bovine spongiform encephalopathy (BSE) control measures: The BSE Control Model. Preventive Veterinary Medicine, 2010; 93(2-3):170-182.

38. Saunier R. Risques sanitaires au regard de l'ESB liés aux rejets dans l'environnement des effluents et boues issus d'abattoirs et d'équarrissages. Agence Francaise de Securite Sanitaire des Aliments, France, September 2003.

39. Seidel B, Thomzig A, Buschmann A, Groschup MH, Peters R, Beekes M, Terytze K. (2007) Scrapie Agent (Strain 263K) can transmit disease via the oral route after persistence in soil over years. PLoS ONE, 2: e435.

40. Georgsson G, Sigurdarson S, Brown P. Infectious disease of sheep scrapie may persist in the environment for at least 16 years. Journal of General Virology, 2006; 87(12):3737-3740.

41. Animal Health. Animal By-Product Database (location of TSE tests and number of ABPR licenses). Accessed December 2009.

42. Buncic S. The levels of pathogens in abattoir wastes: A report to the Food Standards Agency (B05008). Food Standards Agency. July 2002. 